\title{
A Strategic Analysis of the Greek Leisure Tourism: Competitive Position, Issues and Challenges
}

\author{
Prof Marios D. Sotiriadis
}

\author{
Visiting Professor, University of South Africa (UNISA),Department of Transport Economics, Logistics \& Tourism, \\ Pretoria, South Africa \\ sotirm@unisa.ac.za / sotermarios@gmail.com
}

Prof Stelios Varvaressos

Professor, TEl of Athens,Department of Business Management (Tourism Degree), Athens, Greece svarsos@teiath.gr

\section{Doi:10.5901/mjss.2015.v6n1s1p319}

\section{Abstract}

All Mediterranean countries adopted and implemented more or less the same model of tourism development based on 4Ss (Sun, Sea, Sand and Sex). The main purpose of this paper is to analyse the experience of developing leisure tourism in Greece in order to draw some useful lessons for other countries and tourism destinations. To address the research aim this paper adopts the approach of strategic analysis. This approach illustrates the importance of tourism as an economic activity and analyses the current situation and structural problems of Greece as a destination. Although Greece has a wonderful range of natural, cultural and heritage resources, the lack of differentiation of the tourism offering as well as competitive disadvantages in the fields of governance, planning and marketing caused an over-dependence on tour operators for the promotion and distribution of its tourism offering. The same factors compromised the quality of tourism services having involved a vicious circle. This situation has a negative impact on the sustainability and competitiveness of the destination and tourism industry. Therefore, the paper assesses the Greek experience with the aim to identify the crucial issues and challenges. This evaluation permits to take some lessons from the Greek experience, beneficial to other destinations willing to develop tourism, and to formulate some recommendations.

Keywords: Seaside leisure tourism, Greece, Strategic analysis, Competitiveness, TTCI, Structural problems, Challenges.

\section{Introduction}

The purpose of this article is twofold: (i) to evaluate the Greek experience in developing 4Ss tourism, and (ii) to identify and highlight the crucial issues and related challenges. This evaluation permits to take some lessons beneficial to other destinations willing to develop tourism. The study's aim is addressed by applying the methodology of strategic analysis.

In the first section the Greek tourism is presented, highlighting the contribution of tourism to the national economy and demonstrating its achievements and successes. The next section deals with the strategic situation analysis of Greek tourism by analysing the two main components of tourism industry, presenting the performance of Greece over the last years according to the travel and tourism competitiveness index (TTCl), and performing a strengths-weaknessesopportunities-threats (SWOT) analysis to demonstrate its competitive position. Despite its growth over the last decades and the relative high attractiveness, the Greek tourism industry has reached a stage where both its potential and competitiveness have become unsustainable. The last section is devoted to the structural problems, issues, as well as challenges to be addressed. The article is completed by discussing the lessons from the Greek experience and formulating recommendations for destination planners and managers.

\section{The Contribution of Tourism to the Greek Economy}

Greece has been an attraction for international visitors since antiquity for its rich and long history, Mediterranean coastline and beaches (Gerrard, 2014). Greece launched its tourism in the international arena, which started flourishing in the early 1970s with its rich history, many cultural, natural and historical resources, fascinating culture, iconic sights, and the colorful cuisine. In a slow but stable pace, Greece has today managed to become one of the most favourite tourism 
destinations among Europeans, Asians and Americans. The country has all those factors that have been a big draw and will continue to be for inbound tourists to visit its islands and cities.

Figure 1: Map of Greece

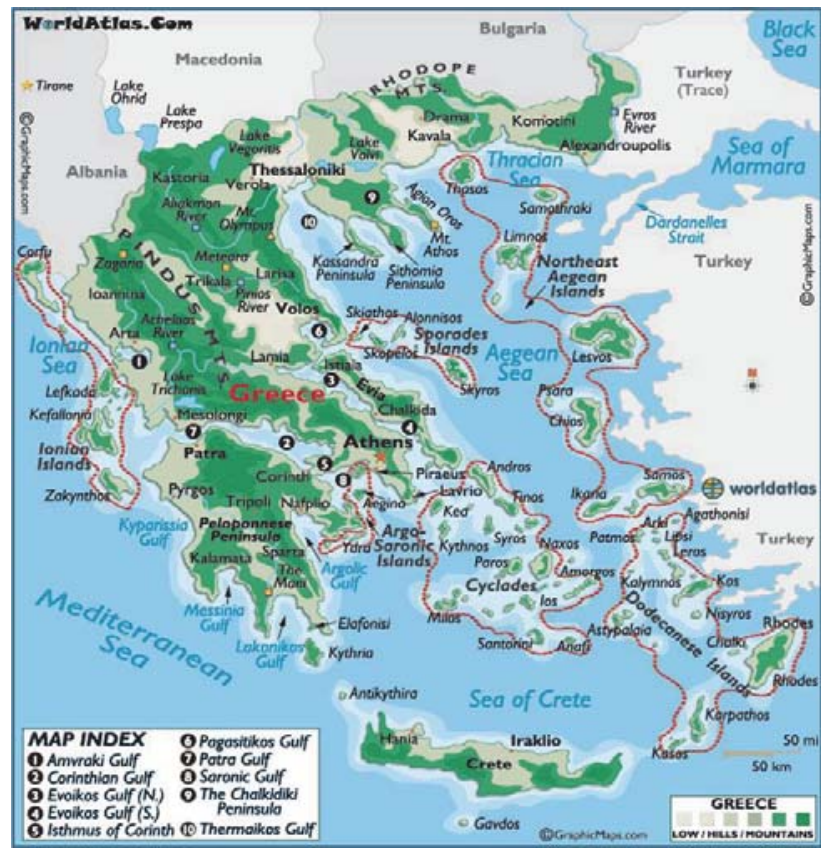

Source: http://www.worldatlas.com/webimage/countrys/europe/lgcolor/grcolor.htm

Tourism started to flourish in what became known as mass tourism (Buhalis, 2001). During that time, large-scale construction projects for hotels and other similar facilities were undertaken and the country saw an increase in inbound tourism over the years (Varvaressos, 2008). Greece is surrounded by water and consists of more than 1,400 islands and islets, but only 169 of them are inhabited. These Greek islands are the most popular Greek destinations (Gerrard, 2014; VisitGreece, 2014).

\subsection{Greece: Economy - Key Indicators}

The key indicators that give a sense of the size of the country and its economy are depicted in the following table (Table 1)

Table 1: Greece - Key Indicators (Year 2013)

\begin{tabular}{|l|c|}
\hline Key indicators & \\
\hline Population (Total) & 11.03 millions \\
\hline Surface area (1,000 square kms) & 132.0 \\
\hline Gross Domestic Product (current US\$ billions) & 241.7 \\
\hline GNI per capita, PPP (current purchasing power parity \$) & $24,678.5$ \\
\hline Real GDP Growth (annual \%) & -3.9 \\
\hline Environmental Performance Index 2012, rank (out of 132 economies) & 33 \\
\hline
\end{tabular}

Source: World Bank, 2014 and World Economic Forum, 2013

\subsection{Tourism in Greece: Travel and Tourism Indicators}

The key role of tourism in the Greek economy has been highlighted by SETE (2013): it contributes $16.2 \%$ to the GDP, covers $51.2 \%$ of the trade balance deficit, employs 1 out of 5 residents, and generates 34 billion euros total demand. This subsection presents Travel \& Tourism (T\&T) indicators that aim to provide a measure of the past and current activity of 
T\&T in Greek economy. The contribution of tourism to Greek economy is shown in table 2.

Table 2: Tourism Industry in Greece - Main Indicators (Year 2013)

\begin{tabular}{|l|c|}
\hline Indicators & Year 2013 \\
\hline International Tourist Arrivals & 16.4 millions \\
\hline International Tourism Receipts & 11.23 billion $€$ \\
\hline Contribution to GDP & $16.2 \%$ \\
\hline Contribution to employment & $18.2 \%$ \\
\hline Average per Capita Tourism Expenditure & $646 €$ \\
\hline European Market Share & $2.9 \%$ \\
\hline World Market Share & $1.5 \%$ \\
\hline
\end{tabular}

Source: SETE (Greek Tourism Confederation), 2014; WTTC, 2014

The tourism industry has been and still is one of the main pillars of the Greek economy over a period of more than forty years. It has been proved that tourism industry has supported and still does economic development because the industry cuts across and is linked to many other industries, and its benefits are widely distributed within national economies. In comparison to other industries, it possesses distinct advantages as a driver of economic development (Oxford Economics, 2012). More specifically: (i) tourism has strong linkages to other industries within national economies generating significant indirect benefits; (ii) it is highly dispersed within national economies and its benefits are widely distributed; and (iii) it generates valuable spinoff benefits by developing infrastructure that other industries can use, and by boosting investments in other industries.

The above reasons and factors led the Greek government, as many others all over the world, to consider tourism industry as an integral part of its economic and social development strategy. Within this framework, policies were elaborated to foster the tourism development, with the strategic aim to generate a broad set of benefits that extend through the entire Greek economy. A situation analysis in strategic terms should allow us to identify and to highlight the achievements of tourism industry in Greece. This is the subject of the following section.

\section{Greek Tourism: A Strategic Situation Analysis}

The contribution of Greek tourism to the national economy demonstrates the magnitude and complexity of the industry (Buhalis, 2001; Varvaressos, 2008). A strategic situation analysis consists of examining the two main components of tourism industry, demand and supply. A second subsection is dealing with the competitive position of Greek tourism, based on the estimations of Travel \& Tourism Competitiveness Index (TTCl). This is followed by a strengthsweaknesses-opportunities-threats (SWOT) analysis to demonstrate the competitiveness of tourism industry.

\subsection{Tourism Demand for Greece: Inbound Tourists}

A comprehensive image of inbound/international tourism over the period 1995-2013 is shown in Table 3.

Table 3: Inbound tourism: arrivals, receipts and overnight stays (Years 1995 to 2013)

\begin{tabular}{|c|c|c|c|}
\hline Year & $\begin{array}{c}\text { International tourist arrivals } \\
\text { (millions) }\end{array}$ & $\begin{array}{c}\text { International tourism receipts } \\
\text { (US\$, billions) }\end{array}$ & $\begin{array}{c}\text { Total of overnights spent } \\
\text { (millions) }\end{array}$ \\
\hline 1995 & 10.13 & 7.91 & 112.35 \\
\hline 2000 & 13.10 & 11.23 & 137.62 \\
\hline 2005 & 14.80 & 14.02 & 153.44 \\
\hline 2010 & 15.07 & 12.72 & 140.18 \\
\hline 2011 & 16.37 & 14.50 & 150.98 \\
\hline 2012 & 15.52 & 14.23 & 140.92 \\
\hline 2013 & 16.43 & 14.62 & 148.52 \\
\hline
\end{tabular}

Source: Hellenic Statistical Authority (HSA), 2014 
The vast majority of international tourists in the country are from Europe, especially from the European Union (EU) countries, followed by those from Asia and the Americas (SETE, 2013). The expenditure per trip and average duration of stay are illustrated in table 4.

Table 4: International tourists in Greece: Expenditure per trip, per overnight spent and average duration of stay (Years 2006 - 2013)2003200420052006 200720

\begin{tabular}{|l|c|c|c|c|c|c|c|c|}
\hline & 2006 & 2007 & 2008 & 2009 & 2010 & 2011 & 2012 & 2013 \\
\hline Average tourism expenditure per capita( $(€)$ & 745.9 & 700.2 & 730.0 & 697.3 & 640.4 & 639.6 & 646.0 & 659.0 \\
\hline Average expenditure per overnight $(€)$ & 70.0 & 70.2 & 76.3 & 73.5 & 68.6 & 68.7 & 71.0 & 65.9 \\
\hline Average duration of stay (in overnights) & 10.7 & 10.0 & 9.6 & 9.5 & 9.3 & 9.3 & 9.1 & 10.0 \\
\hline
\end{tabular}

Source: SETE, 2014 based on data provided by Bank of Greece.

As it has been already stated, the main origin markets for Greece are European, namely England, Germany, FYROM (Former Yugoslav Republic of Macedonia), France and Russia. A better image is provided in the following table (Table 5).

Table 5: The top 10 origin markets (Year, 2012)

\begin{tabular}{|l|c|c|}
\hline Country & \multicolumn{2}{|c|}{2012} \\
\hline & Arrivals & Share (\%) \\
\hline Germany & $2,108,787$ & 13.6 \\
\hline United Kingdom & $1,920,794$ & 12.4 \\
\hline FYROM & $1,300,000$ & 8.4 \\
\hline France & 977,376 & 6.3 \\
\hline Russia & 874,787 & 5.6 \\
\hline Italy & 848,073 & 5.5 \\
\hline Serbia / Montenegro & 620,450 & 4.0 \\
\hline Turkey & 602,306 & 3.9 \\
\hline Bulgaria & 599,110 & 3.9 \\
\hline Netherlands & 478,483 & 3.1 \\
\hline Total of 10 markets & & $66.7 \%$ \\
\hline
\end{tabular}

Source: SETE, 2013 based on data by HSA and the Bank of Greece

Main characteristics of Greek tourism are: (i) the seasonality of international tourist arrivals. Four months (i.e. June, July, August and September) account for almost $70 \%$ of the total; out of them three months (i.e. July, August and September) representing $56 \%$. It seems that the main elements of attractiveness are the sunny weather and warm and clean beaches. (ii) the dependence upon the air transport accounting for $75 \%$ of the total inbound tourism. Greek tourism is heavily dependent on air transport, mainly charter flights operated by tour operators.

\subsection{Tourism Supply in Greece}

A modern industry has emerged since the early 1970s to cater for the inbound tourism demand. The Greek tourism offering is an amalgam of natural, cultural and heritage attractions spread throughout the country, as well as a wide variety of services offered predominantly by SMTEs (Buhalis, 2001; Varvaressos, 2008). Moreover, 24,000 Kms of coastline, 2,500 islands, an average of 300 sunny days annually, a unique fauna and flora, as well as climatic superiority with mild winters and warm summers are some of its natural attractions (Gerrard, 2014). The Greek civilisation of more than 3,500 years also provides plentiful cultural heritage throughout the country. Historical monuments and archaeological sites, numerous museums and traditional settlements offer a unique blend of tourist attractions (VisitGreece, 2014).

As for the transports, accessibility to the country is facilitated through thirty-two airports, most of which can receive direct international charter flights. An extensive domestic regular flights network, a complex network of sea, road and rail transport enables passenger transportation throughout the country (Varvaressos, 2008). The transport networks (especially road) could be considered of good quality, since they have been improved last decade with public investment 
and EU financial support. Tourism businesses / amenities: a plethora of SMTEs provide the entire variety of services. In December 2013, a total of 9,670 official accommodation units with a total capacity of more of 771,000 beds are provided (see Table 6). Two features worth to be pointed out (SETE, 2013): (i) Category of hotels: $68 \%$ of units and $57 \%$ of beds are of 2 and 3 stars. (ii) Concentration of hotel supply: $65.8 \%$ of beds are located in 4 regions: Crete (21.4\%), Dodecanese (18.4\%), Macedonia (14.0\%), and Central Greece (12.0\%).

Table 6: Hotel Supply (Year 2013)

\begin{tabular}{|c|c|c|c|c|}
\hline Category (Star rating) & Hotel units & Distribution of units in percent & Hotel beds & Distribution of beds in percent \\
\hline 5 star & 348 & 3.6 & 113,679 & $14.7 \%$ \\
\hline 4 star & 1,247 & 12.9 & 193,629 & 25.1 \\
\hline 3 star & 2,330 & 24.1 & 183,328 & 23.8 \\
\hline 2 star & 4,236 & 43.8 & 225,508 & 29.2 \\
\hline 1 star & 1,509 & 15.6 & 55,127 & 7.2 \\
\hline Total & 9,670 & $100.0 \%$ & 771,271 & $100.0 \%$ \\
\hline
\end{tabular}

Source: Hellenic Chamber of Hotels, in SETE, 2014

Moreover 500,000 beds are provided by some 30,000 self-catering accommodation units. In addition, 16,000 beds in cruise liners and 13,200 in yachts as well as 314 camping sites (86,958 camping spaces) accommodate all types of demand (Eurostat, 2013). As for other providers of tourism services in Greece, about 26,500 restaurants, 3,855 travel agencies and coach rentals and 4,560 car rental firms are estimated to operate throughout the country (Eurostat, 2013).

As for the infrastructure, unfortunately, the Greek general infrastructure has been incapable of supporting the tourism superstructure growth of the last decades, and thus, telecommunications, transportation, health services, water supply, and sewage systems are under extreme pressure in the summer peak months to satisfy the demand density (Varvaressos et al., 2013). Limited infrastructure provisions which failed to follow the pace of development, generating pressure on the existing inadequate facilities (Varvaressos \& Soteriades, 2008). Nevertheless during the last decade several major projects have been initiated to improve mainly transport systems. These developments have improved the country's infrastructure; however there are still problems.

Policy and Promotion: The implementation of the national tourism policy is supervised by the Ministry of Tourism and the Greek National Tourism Organisation (GNTO). The two organisations share the responsibilities for planning, implementation and promotion of Greek tourism at national and regional level, as well as coordinating the involvement of the public and private stakeholders in tourism (Pastras \& Bramwell, 2013). The Greek tourism is promoted by the global GNTO network performing all the marketing functions, both for individual and institutional customers. Distribution: The Greek tourism offering / products are distributed to the international market predominantly through European tour operators, which organise package holidays and include resorts in their brochures (Bastakis et al., 2004; Soteriades \& Arvanitis, 2006). More than 4,300 incoming travel agencies often act as tour operators' representatives at destinations and handling agencies, while providing a variety of tourism services. In addition, the GNTO and Municipalities operate several information offices at major resorts.

\subsection{Competitiveness: Concept and its Evaluation}

Competitiveness is a comparative concept of the ability and performance of a company, industry, sector or country to sell and supply goods and/or services in a given market. The concept is widely used in business management and economics. Competitiveness captures the awareness of both the limitations and challenges posed by global competition, at a time when effective government action is constrained by budgetary constraints and the private sector faces significant barriers to competing in domestic and international markets. The Global Competitiveness Report of the World Economic Forum (WEF) defines competitiveness as "the set of institutions, policies and factors that determine the level of productivity of a country." (WEF, 2011: 2).

\subsubsection{Tourism Destination Competitiveness}

According to Vanhove (2011), the concept of competitive destination contains two elements: destination and competitiveness. A tourism destination is a well-defined geographical area within which the tourists enjoy various types of 
tourism experiences. It is believed that competition in tourism is mainly between clusters and not so much between countries (Sotiriadis, 2012). Applied to tourism the concept of Porter's cluster, it might be defined "as a group of tourism attractions, enterprises and institutions directly or indirectly related to tourism and concentrated in a specific geographical area" (Vanhove, 2011: 108).

Competitiveness has become a central point of tourism policy. As tourism activity intensifies and competition increases, tourism policy focuses on improving competitiveness by creating a statutory framework to protect resources, and to monitor, control and enhance quality and efficiency in the industry (Goeldner et al., 2000). Within this context, various organisations and scholars developed and suggested frameworks and models to enhance and assess tourism competitiveness. One of these models is the Travel and Tourism Competitiveness Index (TTCI).

\subsubsection{The Travel and Tourism Competitiveness Index}

The TTCI is a holistic platform, jointly developed by international bodies and organizations (i.e. the WEF, IATA, UNWTO, and WTTC). This tool has been developed within an effort to better understand the drivers of T\&T competitiveness and the challenges that face the industry.

The aim and objectives of the TTCl are (Dwyer et al., 2011): (i) to help to explore the factors driving T\&T competitiveness worldwide, thus providing a basis for implementing policies on a country-by-country basis; (ii) to provide a comprehensive strategic tool for measuring the factors and policies that make it attractive to develop the T\&T industry in different countries; and (iii) to provide benchmarking tools that enable countries to identify key obstacles to competitiveness, and to provide a platform for dialogue among government, business and civil society to discuss the best ways of removing them. Its results can be used by all stakeholders to work together to improve the industry's competitiveness in their national economies, thereby contributing to national growth and prosperity (WEF, 2011). It is believed that $\mathrm{TTCl}$ is a useful initiative that allows different countries to assess their performance (i.e. destination competitiveness) against other countries at various levels of development. Further, TTCI is a useful basis for policy making to enhance tourism's potential as an engine for growth. This framework was used to evaluate the performance of Greek tourism industry.

\subsection{The Competitive Position of Greek Tourism}

This section presents the country's performance on the $\mathrm{TTCl}$ and its various components ${ }^{1}$. The competitive score and ranking for Greece over the last years are shown in table 7.

Table 7: TTCI for Greece (Years 2008-2013)

\begin{tabular}{|c|c|c|}
\hline \multirow{2}{*}{ Year } & \multicolumn{2}{|c|}{ TTTCI Greece } \\
\cline { 2 - 3 } & Rank (out of 140) & Score (1-7) \\
\hline 2008 & 22 & 4.9 \\
\hline 2009 & 24 & 4.9 \\
\hline 2011 & 29 & 4.8 \\
\hline 2013 & 32 & 4.8 \\
\hline
\end{tabular}

Source: WEF, 2008, 2009, 2011 and 2013

From the above table it is evident that the competitive position of Greece has been deteriorated over the last six years. Greece is facing competition from traditional and emerging destinations, active in the global tourism arena and aiming at market shares. That is why it is necessary to reposition the Greek tourism offering in the global market by improving, differentiating and enriching its offering (Varvaressos and Soteriades, 2011a).

Let us consider the performance of the Greek tourism compared to its competitors. The evaluation of performance of Greece and of its main Mediterranean competitors (Spain, Croatia, Turkey and Egypt) in terms of TTCI is depicted in tables 8 and 9 .

\footnotetext{
1 The full version of the Report with Country/Economy Profiles and Data Tables is available at: www.weforum.org/ttcr. For further analysis, the data tables at the end of the Report provide detailed rankings and scores for each of the variables included in the TTCI. 
Table 8: Travel \& Tourism Competitiveness Ranking (Year 2013)

\begin{tabular}{|c|c|c|c|c|c|c|c|c|c|c|}
\hline Country & \multicolumn{2}{|l|}{ Greece } & \multicolumn{2}{|l|}{ Spain } & \multicolumn{2}{|l|}{ Turkey } & \multicolumn{2}{|l|}{ Croatia } & \multicolumn{2}{|l|}{ Egypt } \\
\hline Index - Main elements & \begin{tabular}{|c|} 
Rank (out of \\
$140)$
\end{tabular} & $\begin{array}{l}\text { Score } \\
(1-7)\end{array}$ & $\begin{array}{c}\text { Rank (out of } \\
140)\end{array}$ & $\begin{array}{l}\text { Score } \\
(1-7)\end{array}$ & \begin{tabular}{|c|} 
Rank (out of \\
$140)$
\end{tabular} & $\begin{array}{c}\text { Score } \\
(1-7)\end{array}$ & \begin{tabular}{|c|} 
Rank (out of \\
$140)$
\end{tabular} & $\begin{array}{l}\text { Score } \\
(1-7)\end{array}$ & $\begin{array}{c}\text { Rank (out of } \\
140)\end{array}$ & $\begin{array}{c}\text { Score } \\
(1-7)\end{array}$ \\
\hline T\&T Competitiveness Index & 32 & 4.8 & 4 & 5.4 & 46 & 4.4 & 35 & 4.6 & 85 & 3.9 \\
\hline T\&T Regulatory framework & 39 & 5.0 & 14 & 5.5 & 64 & 4.6 & 42 & 5.0 & 86 & 4.4 \\
\hline $\begin{array}{l}\text { Business environment \& } \\
\text { infrastructure }\end{array}$ & 33 & 4.7 & 5 & 5.3 & 52 & 4.1 & 39 & 4.4 & 77 & 3.6 \\
\hline $\begin{array}{l}\text { T\&T human, cultural \& natural } \\
\text { resources }\end{array}$ & 30 & 4.6 & 6 & 5.4 & 27 & 4.6 & 42 & 4.4 & 84 & 3.7 \\
\hline
\end{tabular}

Source: WEF, 2013

Table 9: The TTCI in detail (Year 2013)

\begin{tabular}{|l|c|c|c|c|c|c|c|c|c|c|}
\hline Country & \multicolumn{2}{|c|}{ Greece } & \multicolumn{2}{c|}{ Spain } & \multicolumn{2}{c|}{ Turkey } & \multicolumn{2}{c|}{ Croatia } & \multicolumn{2}{c|}{ Egypt } \\
\hline Indicator & Score & Rank & Score & Rank & Score & Rank & Score & Rank & Score & Rank \\
\hline $1^{\text {st }}$ pillar: Policy rules and regulations & 4.2 & 98 & 4.5 & 67 & 4.9 & 34 & 4.2 & 96 & 4.4 & 76 \\
\hline $2^{\text {nd }}$ pillar: Environmental sustainability & 4.5 & 72 & 5.2 & 25 & 4.3 & 95 & 4.9 & 44 & 4.0 & 121 \\
\hline $3^{\text {rd }}$ pillar: Safety and security & 4.7 & 69 & 5.7 & 23 & 4.6 & 79 & 5.3 & 38 & 2.7 & 140 \\
\hline $4^{\text {th }}$ pillar: Health and hygiene & 6.4 & 13 & 6.1 & 24 & 4.9 & 64 & 6.0 & 31 & 5.3 & 57 \\
\hline $5^{\text {th }}$ pillar: Prioritization of T\&T & 5.2 & 28 & 5.9 & 10 & 4.5 & 63 & 4.5 & 61 & 5.5 & 18 \\
\hline $6^{\text {th }}$ pillar: Air transport infrastructure & 4.7 & 20 & 5.3 & 10 & 4.5 & 29 & 3.0 & 68 & 3.4 & 57 \\
\hline $7^{\text {th }}$ pillar: Ground transport infrastructure & 4.0 & 58 & 5.9 & 10 & 4.1 & 52 & 4.1 & 53 & 3.1 & 96 \\
\hline $8^{\text {th }}$ pillar: Tourism infrastructure & 6.8 & 3 & 6.7 & 5 & 4.8 & 45 & 6.7 & 5 & 2.9 & 90 \\
\hline $9^{\text {th }}$ pillar: ICT infrastructure & 4.3 & 33 & 4.5 & 28 & 3.1 & 71 & 4.3 & 30 & 2.8 & 80 \\
\hline $10^{\text {th }}$ pillar: Price competitiveness in T\&T & 3.6 & 127 & 4.1 & 106 & 4.0 & 112 & 4.0 & 109 & 5.6 & 4 \\
\hline $11^{\text {th }}$ pillar: Human resources & 5.0 & 50 & 5.2 & 34 & 4.9 & 68 & 4.6 & 93 & 4.4 & 105 \\
\hline $12^{\text {th }}$ pillar: Affinity for T\&T & 4.8 & 55 & 4.9 & 39 & 5.0 & 35 & 5.1 & 29 & 4.7 & 60 \\
\hline $13^{\text {th }}$ pillar: Natural resources & 4.2 & 40 & 4.8 & 29 & 3.4 & 78 & 3.8 & 56 & 3.3 & 87 \\
\hline $14^{\text {th }}$ pillar: Cultural resources & 4.3 & 25 & 6.6 & 1 & 5.2 & 19 & 3.9 & 32 & 2.6 & 61 \\
\hline
\end{tabular}

Source: WEF, 2013

From the above tables it is evident what are the competitive advantages, the strengths and weaknesses of Greek tourism industry. These elements are useful inputs for the SWOT analysis. It is worth pointing out that when implementing such an analysis, there is a need to ask and answer questions that generate meaningful information for each category to make the analysis useful (Vanhove, 2011).

\subsection{SWOT Analysis for Greek Tourism}

A SWOT analysis ${ }^{2}$ is carried out for the Greek tourism as well as its SMTEs in order to assess their present and forecasted competitiveness, based on strategic management research undertaken (Buhalis, 2001; Varvaressos \& Soteriades, 2011b), as well as on the estimations of the TTCl, outlined above (WEF, 2013). The interrelations between SMTEs and destinations are quite apparent, illustrating that a destinations' weaknesses and threats are reflected in the

${ }^{2}$ A SWOT analysis is a structured planning method used to evaluate the strengths, weaknesses, opportunities and threats involved in a project, organisation, business venture, place or industry. It involves specifying the objective of the business venture or organisation and identifying the internal and external factors that are favourable and unfavourable to achieve that objective. Thus, it aims to identify the key internal and external factors seen as important to achieving an objective. The results are often presented in the form of a matrix. It classifies key pieces of information into two main categories: (i) Internal factors - the strengths and weaknesses internal to the organization. Strengths: characteristics of the business or industry that give it an advantage over others. Weaknesses: characteristics that place the business or industry at a disadvantage relative to others. (ii) External factors - the opportunities and threats presented by the environment external to the organization; in other words, Opportunities: are elements that the organisation could exploit to its advantage. Threats: are elements in the environment that could cause trouble for the business or industry (Okumus et al., 2010). 
SMTEs' competitiveness and vice versa (Vanhove, 2011).

As illustrated in Table 10, the following strengths (valuable assets) of the Greek tourism could be identified: (i) tourism resources (archaeological, heritage, natural and cultural), (ii) the SMTEs' flexibility and ability to tailor products to new, savvy tourists' needs, (iii) personal relationships with consumers, suppliers and employees, (iv) Entrepreneurial activity and family involvement enhancing service quality and customer satisfaction, (v) Air transport infrastructure, and (vi) Health and hygiene systems.

The main weaknesses of Greek tourism are (i) Management of SMTEs: Lack of strategic and operational management know-how generates inconsistency in the creation and delivery of tourism products. This has direct implications for tourists' satisfaction. (ii) Marketing is another significant weakness for most tourism providers, as they often follow a product-oriented rather than a consumer-orientated approach, SMTEs seem to be incapable in promoting themselves effectively. Thus, SMTEs suffer from over-dependence on the tourism distribution channels to market their product. In particular, tour operators have enormous power within the channel and are capable of determining the marketing, and distribution of Greek tourism offering (Bastakis et al., 2004). European tour operators also control accessibility to destinations, as they own most charter airlines which provide direct flights. (iii) Lack of economies of scale and low bargaining power. (iv) Significant financial constraints, inadequate training procedures, no quality standards and seasonality problems. (v) SMTEs' typical lack of business expertise and professionalism don't help in properly respond to an increasingly demanding customer (Soteriades, 2012). (vi) Other weaknesses: no steady policy rules and regulations, high cost of living, absence of efforts and resources toward environmental sustainability, and no satisfactory ground transport infrastructure.

Table 10: SWOT Analysis of Greek tourism

\begin{tabular}{|c|c|}
\hline 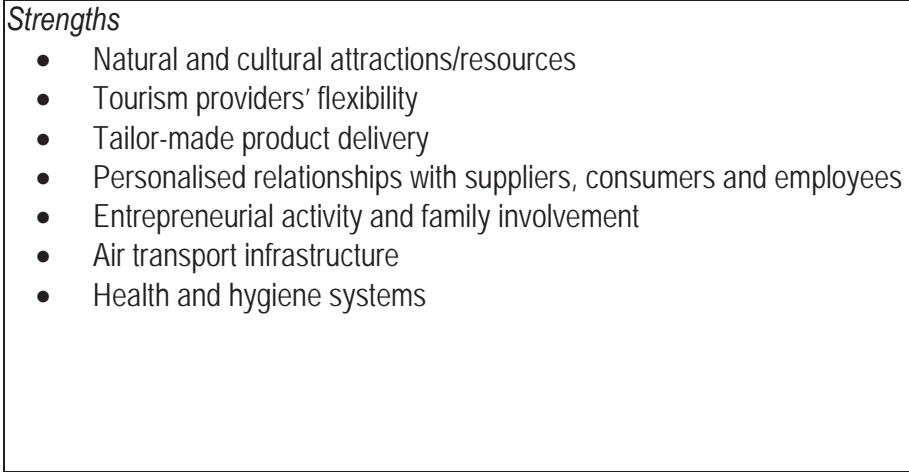 & 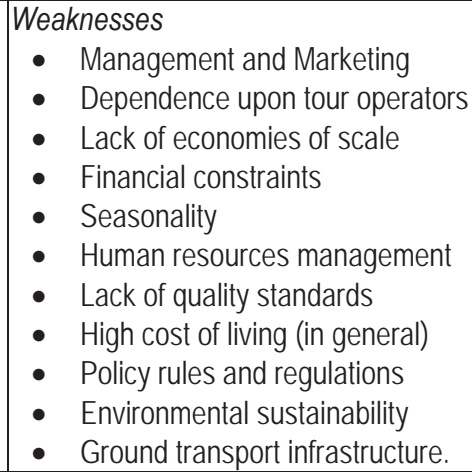 \\
\hline $\begin{array}{l}\text { Opportunities } \\
\text { - Information technology } \\
\text { - Transportation (low-cost carriers) } \\
\text { - European Union support } \\
\text { - Increase in tourism demand size } \\
\text { - New emerging markets, China and Russia } \\
\text { - Trends in tourism demand } \\
\text { - Infrastructure development }\end{array}$ & $\begin{array}{l}\text { Threats } \\
\text { - Environmental degradation } \\
\text { - } \text { Oversupply } \\
\text { - } \text { Loncentration and globalisation } \\
\text { - Infrastructure } \\
\text { - Political crises/Wars/terrorism } \\
\text { Political intervention }\end{array}$ \\
\hline
\end{tabular}

Source: Buhalis, 2001; Varvaressos \& Soteriades, 2011b; WEF, 2013

Opportunities: the main opportunities for the Greek tourism industry are resulting from the developments in the external environment. Firstly, the information and communication technologies (ICTs) can offer opportunities and provide strategic tools for tourism destinations and SMTEs enabling them to manage efficiently their offering, disseminate information and establish a distribution mechanism (Buhalis, 2001). (ii) Deregulation of air transport and the low-cost carriers are favourable developments (Doganis, 2006; Katarelos \& Koufodontis, 2012). For instance, the launch of Ryanair flights to and from Greece greatly contributed to growth in 2013. (iii) Furthermore, the EU takes several actions to support SME, while it supports infrastructure development of peripheral regions and contributes significantly to the prosperity of SMTES. (iv) The country is going through a major transformation as a result of several public projects supported by the EU. In addition, several projects are anticipated to improve the superstructure of the industry. (v) Greek tourism benefits from the 
continuous growth of global tourism demand, especially from the emerging markets, as more people require travel and tourism services, while SMTEs are expected to increase their share as they tend to satisfy the emerging specialised demand better than larger organisations (Sotiriadis, 2012).

As for the external threats, the following could be observed (i) Environmental degradation through inappropriate waste management and excessive usage of natural resources. The lack of know-how and funds effectively increases environmental problems. (ii) Moreover, oversupply of tourism service providers and lack of well-defined carrying capacity limits in several destinations have placed numerous Greek areas and SMTEs in a disadvantaged position as they cannot achieve sufficient income (Varvaressos, 2008). (iii) Similarly, the concentration of power in fewer tourism industry corporations through emerging globalisation also threatens the ability of Greek SMTEs to survive, as international vertically integrated tourism organisations acquire control over local enterprises. (iv) The dependence upon channel partners for the promotion and distribution of Greek tourism is exaggerated by the relatively low presence of Greek suppliers in the major GDSs (Global Distribution Systems). (v) The issue of infrastructure is closely related to the oversupply which attracts higher demand than planned. (vi) Further, the tourism industry suffers from its geographical proximity to the Balkans and the Middle East and as a consequence is often associated by consumers with wars and terrorism activities (Buhalis, 2001). Last but not least, political intervention often damages the prosperity of SMTEs (Varvaressos, 2008).

The SWOT analysis demonstrates quite clearly that the Greek tourism faces a wide range of problems and threats which jeopardise its ability to provide high quality tourism experiences, as well as its ability to make a contribution to the national prosperity. However, several opportunities and challenges emerge and they need to be addressed in order to strengthen the tourism's competitiveness. It is therefore necessary to proceed to further analysis aiming to assess the factors which generate these problems and the related challenges.

\section{Structural Problems, Issues and Challenges}

Despite the growth of tourism, the significant contribution and the relative high attractiveness, the Greek tourism industry has reached a stage where both its potential and competitiveness have become unsustainable. Tourism development in almost all areas took place without any development plan, respect of the landscape and environment and demand analysis (Varvaressos et al., 2013). From the point of view of competitiveness, the Greek tourism is not anymore 'good value for money' (Varvaressos \& Soteriades, 2008). The leisure tourism market doesn't perceive the country as cheap in relation to comparable destinations in the Mediterranean. Further, much of the country's tourism infrastructure does not meet the needs of a market less sensitive to price and more concerned with quality and value for money. Hence, unless the Greek tourism industry addresses a number of critical issues immediately, its future might be seriously compromised (Varvaressos, 2008). The major structural problems and challenges for the Greek tourism are presented below.

\subsection{Public Sector: Failure to Properly Fulfil its Role and Functions}

The public sector does not have a long-term strategic vision to the tourism activity. The following main issues could be pointed out: inadequacy of the Greek planning process, unsuccessful and inconsistent government programmes, almost unregulated environment, with nearly complete lack of control, political intervention, and inadequacy of infrastructure to serve the ever-expanding demand. Eventually, the biggest obstacle in developing a competitive tourism industry in Greece has been the irrational political intervention (Buhalis, 2001). Unfortunately, tourism has extensively been utilised as a political vehicle, 'politician practices' resulting in a great inconsistency in tourism policy and disrupt its rationalisation. The lack of a comprehensive and rational tourism policy and planning for Greek tourism is primarily responsible for the above mentioned structural problems (Varvaressos, 2008).

In essence Greek authorities 'determine' tourism policy targets such as increase inbound tourism arrivals and receipts, increase competitiveness of tourism product, extension of tourism season, and attraction of high spenders and alternative types of tourism,. However, as these objectives are not quantified and there is no time plan or process for their achievement, it is inevitable that their implementation and assessment is subject to irrational judgement. Komilis (1993) suggests that tourism planning in Greece is generally realised and exercised within a socio-political environment characterised by a series of factors, such as: a limited degree of political commitment, lack of social awareness and acceptability of planning actions, inadequacy of scientific and technical foundation to support planning intervention, and a centralised administrative-institutional system gathering a plethora of functions, but failing to perform its coordination and enforcing role. Moreover, the different actors attempt to influence legislation in order to maximise their own short-term 
profitability, regardless of the impacts on the destination and other enterprises, the planning process becomes more complicated. This results in an ineffective planning process which produces policies unable to provide an appropriate balance between restrictive policies and control planning implementation. Similarly, the same deficiencies and problems are evident in the field of marketing. The promotional campaign and activities attempt to achieve the above unspecified policy aims, without any long-term strategic marketing approach, including feedback and evaluation of effectiveness of plans (Varvaressos \& Soteriades, 2008).

\subsection{Private Sector}

The plethora of SMTEs, in combination with inadequate legislation concerning their establishment and operation, seem to affect negatively the ability to diversify and enrich local tourism offering and to provide high quality experiences (Varvaressos \& Soteriades, 2011b). Structural problems include plethora of anarchically operating SMTEs, aiming at short-term profitability, oversupply of tourism amenities and fierce price competition, individualistic behaviour by SMTES and unwillingness to cooperate on a destination basis, lack of professionalism, failure to invest in long-term projects, lack of partnerships among destination stakeholders to deal with tourism issues. The main challenge is that there is lack of cooperation at destination level causing serious problems in all fields: quality of experience, tourists' satisfaction, inappropriate promotion and distribution.

As a consequence of the above structural problems there are serious risks for the prosperity of both destinations and tourism providers, especially in overdeveloped regions. On the supply side, failure of the infrastructure to follow the overexpansion of the superstructure, in combination with the lack of solid institutional context of tourism policy and longterm regulation, result in the improper exploitation of environmental and socio-cultural resources, as well as the inability of the industry to generate the level of economic benefits expected. On the tourism demand side, it seems that the Greek tourism providers are not adaptive to tourists' requirements and not able to respond properly.

\subsection{Challenges}

The main challenges to be addressed include: the gradual deterioration of tourism offering, lack of improvement and rejuvenation, the image of cheap and undifferentiated 4Ss destination, the increase of tourism arrivals but decrease of expenditure per capita, the dependence upon tour operators, the development of tourism as a single regional development option, the inability of SMTEs to cooperate and collaborate, the deterioration of natural, social and cultural resources, the failure of both the private and public sectors to learn from internationally gained experience and best practices, and the negligence with regard to new tourism demand challenges.

\subsection{Implications}

Structural problems generate negative tourism impacts in all areas: business, macro-economic, social, cultural and environment. There is a dependency of SMTEs on tour operators as a result of the weak position of the Greek tourist product in the international market and of the lack of marketing activities. This leads to low profitability. Further, the structural problems have profound implications for the prosperity of host populations, as the destinations' economic, social, cultural and environmental resources are exploited without ensuring their sustainability (Tsartas, 1992; Komilis, 1993). Failure to initiate capacity limits or zoning systems contribute to the anarchic development of tourism, as well as expand negative impacts of tourism on local societies and environments. The main of these negative impacts are highlighted below.

Macro-economic impacts: Instead of tourism stimulating agriculture, it seems that it hastens its decline; tourism has been developed at the expense of industrial and agricultural growth. As a result, the economic structure of the destination is jeopardised, while a complete dependence upon tourism becomes inevitable (Komilis, 1993; Varvaressos, 2008). Moreover, there is evidence that the progress of destinations through their life-cycle, and especially the introduction of mass tourism, decreases their economic impacts (Varvaressos \& Soteriades, 2011a). Because of the high degree of dependence of Greek SMTEs on tour operators, the actual amount of tourist spending remaining in the country is only the $40-50 \%$ of total tourist spending (Soteriades \& Arvanitis, 2006).

Social and cultural impacts: The development of mass tourism and the lack of effective planning and management are also responsible for a number of negative social and cultural impacts observed in Greek host societies (Tsartas, 1992; Wickens, 1994; Haralambopoulos \& Pizam, 1996; Andriotis, 2005): the misbehaviour of tourists, aggressive to the host populations and several types of criminal activity; the commercialisation of history, cultural traditions and the Greek 
lifestyle. Briassoulis (1993: 296) perhaps describes best the change in labour force values when as she suggests that tourism has created a peculiar parasitic group of tourist entrepreneurs operating tourist-serving enterprises.

Environmental impacts: most Greek destinations go through an unparalleled exploitation due to inadequate planning having a serious negative effect on their sustainability. Geographical concentration of tourism caused damage to the environment and cultural heritage in the more popular areas. Already the environment has suffered from haphazard, uncontrolled building, and pollution of the sea and the flora and fauna are being affected by waste disposal. Coastal pollution, water shortages, sewage treatment, waste disposal, traffic congestion, noise pollution, overbuilding, and aesthetic degradation are some of the impacts experienced already in a number of resorts (Briassoulis, 1993; Varvaressos, 2008). Urgent coordination with all tourism actors at the local level is essential, while regulation is required to set objective and measurable limits and targets, in order to preserve local environmental resources.

It is argued that these negative impacts emerge as a result of the structural problems of the Greek tourism industry and illustrate that the mass tourism orientation of the industry reduces the control of the local stakeholders over their land and resources whilst jeopardising their expected benefits and future prosperity (Varvaressos \& Soteriades, 2008). As these impacts are trade-offs for the economic gains of the tourism activity, it is important that consistent, long-term strategic planning should be undertaken in order to enable the preservation of tourism resources and achieve sustainability at tourism destinations. The present study suggests that the appropriate approach to tackle these issues is the strategic planning and management.

\section{Conclusion: Lessons and Recommendations}

The fierce competition in the global tourism arena, the mass tourism orientation of the industry, the changes in tourists' behaviour, the increase of the volume of inbound tourism, the dependence upon tour operators for the tourism offering distribution in the major demand markets, the lack of adequate managerial skills by Greek tourism entrepreneurs, and the lack of a development plan by the public sector has led the competitiveness of Greece tourism to decline. This has several negative implications for the tourism providers, as well as negative economic, sociocultural and environmental impacts for the host communities. Based on the strategic analysis of situation and competitiveness, the present study indicates the lessons that could be taken from the Greek experience and formulates recommendations for destination planners and managers.

The main lesson that could be drawn from the above analysis is that Greek tourism has attained great achievements in quantitative terms; it could have performed better if there was an appropriate tourism planning and rational policy. During last decades there was not effective strategic planning for the Greek tourism, in order to provide directions to the destinations in supporting their sustainability and in increasing their competitiveness. Further, its competitiveness should be much better if there has not been a gap between political speeches and action plans, between planning and implementation of development plans. The anarchic tourism development exclusively based upon the market forces (laissez-faire) without any serious regulating and coordinating functions, caused serious structural problems that must be surmounted.

The public sector hasn't played its role as regulator, coordinator, infrastructure provider and promoter of the destination, while a multi-integration of the tourism industry, with all the involved institutions in the design, distribution and delivery of tourism experience opportunities. The private sector also failed to take over its responsibilities, relying almost exclusively on public sector and intermediaries for the marketing of their services. The business sector should have performed better to contribute to tourism industry prosperity by improving its managerial and marketing competencies and cooperating closely in order to achieve synergies and economies of scale. At the same time, in terms of governance, there is a relative failure because of the lack of decentralisation; the local government and authorities do not have the functions and resources to fulfil their significant role in providing high quality tourism offering at local level (Varvaressos, 2008).

All destinations planners, managers and marketers should bear in mind the following issues and challenges in order to attain a sustainable competitive position of tourism industry. The highly competitive global tourism arena is not 'one actor's show' for destinations; all involved stakeholders at destination level should take over their responsibilities and perform properly their respective functions, in close collaboration (Poon, 1993; Morrison, 2013). The public sector, through its institutions and agencies, has to provide a comprehensive framework for strategic planning which will enable the strengthening of the tourism competitiveness (WEF, 2013). Therefore, the initial and crucial step is to determine a clear competitive strategy aiming to establish a profitable and sustainable position in the global marketplace. Within this context, a tourism destination must follow a series of recommendations in order to be sustainable and competitive.

Tourism governance: The appropriate political and institutional approaches are a prerequisite to address the 
challenges and issues. Need to establish the appropriate structures and provide them with the suitable human and financial resources. Cooperation between the tourism providers by means of partnerships and alliances at destination level is not a luxury, is a necessity. It is argued that a co-evolution of structures and practices shapes tourism policies and activities (Pastras \& Bramwell, 2013). The government must coordinate the tourism policies and activities among different actors, institutional arrangements and administrative levels in the fields of destination management and marketing.

Strategic planning: the rational approach to destination planning and management should consist of specific steps and outcomes. A strategy can be implemented for destinations, through a number of strategic directions, resulting to specific aims and precise tasks (action plans) to achieve the quantifiable objectives (Okumus et al., 2010). The strategic aims for the tourism industry of any destination (developed or emerging) should basically be: to offer a series of experience to enhance tourists' satisfaction; to support and strengthen the sustainability and long-term competitiveness of the destination; and to sustainably develop the local destinations and to ensure prosperity of host population. Komilis (1994) indicates that although the various levels of planning (sectoral, national, spatial or regional) are not mutually exclusive, but rather complementary, the regional level planning is more suitable for drawing sustainable strategies. The regional planning should contribute to the maximisation of development benefits in a way that utilises and mobilises the regional resource base, realises regional inter-sectoral linkages and is compatible with economic interests, societal values and environmental assets (Morrison, 2013).

Adequate strategies: the present study argues that every destination needs to focus on the differentiation strategy, define its own niche markets and serve them accordingly. Through such a strategy, destinations should differentiate their tourism offering in order to be able to achieve a unique 'tourist product benefit' which would enable them to establish their position in the global tourism market (Poon, 1993; Morrison, 2013). Destinations should aim to achieve niche orientation, through differentiation, in order to increase consumer satisfaction as well as to maximise the related benefits. It is quite apparent that the cost advantage strategy has to be avoided by insular and remote destinations, as these areas need to preserve their scarce environmental and sociocultural resources and achieve sustainable development (Violier, 2008). As for the overdeveloped destinations, the primary objective should be the minimisation of further sociocultural and environmental damage, as well as the improvement of the surrounding environment. The ultimate aim should be to regenerate the regional resources and to rejuvenate and reposition the destination (Buhalis, 2001; Varvaressos, 2008).

Management: its main focus should be the sustainable development of destination, not only for the host community, but also because this is vital for both tourists' satisfaction and the performance of SMTEs. Therefore, the main objectives must be environmental protection and infrastructure amelioration. The DMO is expected to hold the strategic responsibility of the destination, as well as to regulate the competition. The improvement of public services and local facilities is also a crucial factor. Better quality services would stimulate the competitiveness of tourism offering and strengthen its position in the global market. Further, there is an imperative for a shift in the SMTEs' dependence on tour operators and for the development of a new consciousness in sustainable tourism development which respects the destinations, SMTEs need to create networks and co-operative schemes in an effort to resist the monopolist tour operators' practices.

Tourism should be utilised as the catalyst and major stimulant for regional development. It is suggested that clustering is a suitable alternative option, instead of the formation of strategic alliances for competitive advantage. This approach has increased positive influence on regional development. A major challenge is the economic integration of tourism to the regional productive system; this integration can improve the economic and social benefits of tourism in the region and the efficiency of SMTEs (Violier, 2008). Diagonal integration of destinations' economy can be achieved by rearranging the goods and service production in order to support the tourism industry demand, and thus minimise imports. This strategy for tourism industry should aim to delight tourists, enhance the long-term prosperity of SMTEs, and improve the welfare of the host populations by spreading the benefits of tourism in the whole productive system (Vanhove, 2011). Finally, all stakeholders need to offer a fair return-on-resources utilised back to the host community. A mechanism should be established in order to reinvest part of the revenues in the sustainability of resources and provide services for the host community. This mechanism has never been introduced into the Greek tourism.

Marketing: tourism destinations are not offering any longer products but tourism experiences. It is believed that the offering perceived value for money would determine destinations' competitiveness in the marketplace (Vanhove, 2011; Morrison, 2013). The main strategic aim is to satisfy the specific needs of particular niches and the requirements of the 'new tourism' (Poon, 1993; Pearce, 2011). The shift from the traditional 4Ss (Sun, Sea, Sand and Sex) and a passive nature of tourism to a more active one and the 4ls (standing for Information, Insight, Involvement and Inspiration) as well as the characteristics of SMTEs, and their collective influence on tourism products and destinations determines a framework for innovative actions. The cooperation and collaboration at destination level contribute to the design and offering of customised experiences by using flexibility in order to respond to the new demand trends (Sotiriadis, 2012). An 
integrated communications mix is necessary to maximise the marketing effectiveness, with sufficient financial resources and suitable human resources to attain the aims.

Within this context, the DMO should take advantage of every opportunity - e.g. events, films, etc. - to promote and reposition its tourism. Within the same realm, destinations have to exploit the full potential and take advantage of the opportunities provided by the advent and rapid expansion of ICTs in the tourism field. The continuously changing environment of e-marketing in travel and tourism requires adopting adequate strategy and use of all available tools and techniques to collaborate with the travel trade and the media for their online marketing activities (UNWTO, 2014).

Every destination (spatial zone, city, island, district or region) needs a general strategy as well as a range of strategic directions, objectives and tasks for its tourism industry. This is the responsibility of DMO. The latter has to adopt a comprehensive strategy and to draw up a development plan with quantifiable objectives, tasks and specific action plans (Morrison, 2013). A suitable governance and holistic tourism management system are required to facilitate the development and implementation of the tourism strategy, through investments, monitoring, coordination, regulation and control, as well as evaluation of performance of public- and private-sector actions and practices.

\section{References}

Andriotis, K. (2005). Community group perceptions and preferences for tourism development: Evidence from Crete. Journal of Hospitality and Tourism Research, 29(2), 207-224.

Briassoulis, H. (1993). Tourism in Greece. In: Pompl, W. and Lavery, P. eds. Tourism in Europe: Structures and Developments (pp.285301). Wallingford: $C A B$ International.

Bastakis, K., Buhalis, D. \& Butler, R. (2004). The perception of small and medium sized tourism accommodation providers on the impacts of the tour operators' power in eastern Mediterranean. Tourism Management, 25(2), 151-170.

Buhalis, D. (2001). Tourism in Greece: strategic analysis and challenges. Current Issues in Tourism, 4(5), 440-480.

Doganis, R. (2006). The airline business ( $2^{\text {nd }} \mathrm{ed}$.). London: Routledge.

Dwyer, L., Forsyth, P. \& Dwyer, W. (2011). The Travel and Tourism Competitiveness Index as a Tool for Economic Development and Poverty Reduction. In: Moutinho, L. (ed.) Strategic Management in Tourism, 2nd edn (pp. 33-52). Wallingford: CAB International.

Eurostat (2013). European statistics. Available at: http://epp.eurostat.ec.europa.eul. [September 12, 2014].

Gerrard, M. (2014) National geographic traveler: Greece (4th ed.). Washington DC: The National Geographic Society.

Goeldner, R., Ritchie, J. \& McIntosh, R. (2000) Tourism: Principles, Practices, Philosophies (8th ed.). New York: J. Wiley \& Sons.

Greeka (2014). Tourism in Greece. Available at: http://www.greeka.com/greece-travel/tourism.htm [August 28, 2014].

Haralambopoulos, N. \& Pizam, A. (1996). Perceived impacts of tourism: the case of Samos. Annals of Tourism Research, 23(3), 503526.

Katarelos, E. \& Koufodontis, I. (2012). Business relations between the low cost carriers and airports as a consequence of the air transport deregulation. Journal of Air Transport Studies, 3(1), 57-77.

Komilis, P. (1993). Values in the tourism planning and policy making process. International Conference Proceedings 'Values and the Environment'. (pp. 224-229), 23-24 September. Guildford, UK: University of Surrey.

Komilis, P. (1994). Tourism and sustainable regional development. In: Seaton, A., Wood, R., Dieke, P., and Jeckins, C. eds. Tourism The State of the Art: The Strathclyde Symposium (pp. 65-73). Chichester: J. Wiley \& Sons.

Morrison, A.M. (2013). Marketing and managing tourism destinations. Oxon, UK: Routledge.

Okumus, F., Altinay, L. \& Chathoth, P. (2010). Strategic management for hospitality and tourism. Oxford: Butterworth-Heinemann.

Oxford Economics (2012). The comparative economic impact of travel and tourism. London: Oxford Economics and World Travel \& Tourism Council.

Pastras, P. \& Bramwell, B. (2013). A strategic-relational approach to tourism policy. Annals of Tourism Research, 43(2), 390-414.

Pearce, P.L. (2011). Tourist behaviour and the contemporary world. Bristol: Channel View Publications.

Poon, A. (1993). Tourism, technology and competitive strategies. Wallingford: CAB International.

SETE (Greek Tourism Confederation) (2013). Greek tourism: facts \& figures, edition 2013. Athens: SETE.

Sotiriadis, M. (2012). Tourism destination marketing: Approaches improving effectiveness and efficiency. Journal of Hospitality and Tourism Technology, 3(2), 107-120.

Soteriades, M. \& Arvanitis, S. (2006). Expenditure patterns by travel party size: British and German tourists on Crete, Greece. Anatolia: An International Journal of Tourism and Hospitality Research, 17(2), 169-187.

Tsartas, P. (1992). Socioeconomic impacts of tourism on two Greek isles. Annals of Tourism Research, 19, 516-533.

Vanhove, N. (2011). The economics of tourism destinations (2nd ed.). London: Elsevier.

Varvaressos, S. (2008). Tourism: economic approaches (2nd ed.). Athens: Propobos.

Varvaressos, S. \& Soteriades, M. (2008). La crise du modèle de développement touristique grec. Tourism Issues, 5, 58-78.

Varvaressos, S. \& Soteriades, M. (2011a). The dynamics of tourism and the international environment: the Greek experience. Archives of Economic History, 23(1), 17-39.

Varvaressos, S. and Soteriades, M. (2011b). Destination management: bridging sustainable development opportunities and visitors' quality experiences. Arabian Journal of Management Review, 1(1), 1-16. 
Varvaressos, S., Melissidou, S. \& Sotiriadis, M. (2013). Modular tourism complexes and areas of integrated tourism development as tools of organizing tourism superstructure in Greece; a critical review. Tourism Science Review, 16, 243-245.

Violier, P. (2008). Tourisme et développement local. Paris : Belin

VisitGreece (2014). The Official website of Greek Tourism Organisation. Available at: http://www.visitgreece.gr [September 10, 2014].

Wickens, E. (1994). Consumption of the authentic: the hedonistic tourist in Greece. In: Seaton, A., Wood, R., Dieke, P., and Jeckins, C. eds. Tourism - The State of the Art: The Strathclyde Symposium (pp. 819-25). England: J. Wiley and Sons.

World Bank (2014) World development indicators online database 2014. Available at: http://search.worldbank.org/all?qterm=Greece\& language=EN\&op [September 11, 2014].

World Economic Forum (2011). The travel \& tourism competitiveness reports 2008, 2009 and 2011. Geneva: WEF.

World Economic Forum (2013) The travel \& tourism competitiveness report $5^{\text {th }}$ edition. Geneva: WEF.

UNWTO (2014) Handbook on e-marketing for tourism destinations ( $3^{\text {rd }}$ ed.). Madrid: World Tourism Organisation. 